\title{
Design Calculation of Drill-Injection Piles with Controlled Broadening and Silty-Clayed Soil Foundation Basic Interaction Parameters
}

\author{
Mikhail Samokhvalov ${ }^{1}$, Juriy Zazulya ${ }^{1}$, Roman Melnikov ${ }^{1, *}$ and Victor Mironov ${ }^{1}$ \\ ${ }^{1}$ Industrial University of Tyumen, 625001 Volodarskogo str. 38, Tyumen, Russia
}

\begin{abstract}
The paper describes a new method of drill-injection pile installation formed by the sleeve technology with solution injection using the "fracturing" mode and the controlled broadening at the pile end. This method is aimed at high-quality and effective compaction of the soil under the strip foundation of the reconstructed building. Analyzed are the results of the in-situ tests intended to interaction of drill-injection piles manufactured by the sleeve technology and single and repeated solution injections using the "fracturing" mode and the controlled broadening at the pile end. The radius of the neighboring compacted soil massif zone was determined. The geometric parameters of the pile shaft broadening, and fractures were identified. The algorithm for calculating the basic parameters of the proposed piles was developed in order to forecast their interaction with a silty-clayed soil foundation under static loading. A comparison with classical analytical solutions after soil mechanics, theory of elasticity and plasticity was made.
\end{abstract}

\section{Introduction}

There are a large number of buildings and structures worldwide (including cultural heritage) which are in need of renovation, restoration and modernization in accordance with modern requirements which regulate the development of underground space of the buildings in order the objects of social and engineering infrastructure to be housed there [1 4]. As a rule, they are located in the constrained urban areas of city centers, in difficult engineering-geological and hydrogeological conditions [5-8]. In this regard, it is necessary to develop an efficient and reliable means for strengthening strip foundations by soil foundation compaction $[1,9-11]$.

The analysis of different ways of strengthening revealed that the embedded reinforcing elements of different shapes were of high-priority: piles with the controlled broadening at their ends, drill-injection (injection) piles with broadening in the diameter of the pile shaft and the sleeve technology with solution injection using the "fracturing" mode $[2,10,12$, 13]. At the same time, these ways incorporate the main drawback in a varying degree, i.e. unpredictable and uncontrolled expansion of the solution in silty-clayed soil massif, and as a consequence, possible irregular compressibility of the base in plan and other unfavorable effects $[10,14]$. As a result, to further improve the workability and effectiveness of the

* Corresponding author: tgasu.melnikov.roman@mail.ru 


\section{TPACEE-2016}

proposed strengthening methods, the authors suggest the new combined universal method of drill-injection pile installation manufactured by the sleeve technology with solution injection using the "fracturing" mode and the controlled broadening at the pile end. (Fig. 1).

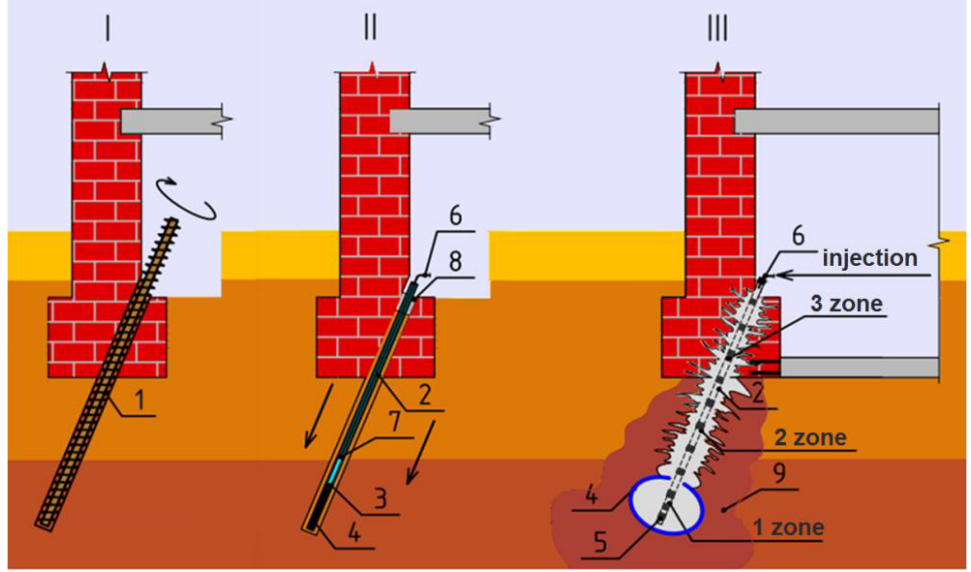

Fig. 1. Schematic illustration of drill-injection pile installation with the controlled broadening: 1borehole, 2-injector tube, 3-clamp, 4- membrane cup, 5-rubber sleeves, 6 - hose, 7-packer, 8-concrete plug, 9-compressed zone of soil massif. [15]

\section{Subject and methods of research}

The injector tube with three zones of perforation is used for pile installation. The first zone is located at the end of the membrane cup, the second - beyond the end zone, and the third in the zone of foundation strengthening. In doing the injection of the first zone the membrane cup is stretched and forms a broadening in the soil massif; the sizes can be controlled with the grout injection pump gauge by the volume flow and solution injection pressure. Then the packer is moved to the second and third zones to form pile shafts; solution injections are done for the foundation members being strengthened using "fracturing" and "healing of cracks" modes. The rubber shell of the membrane fits close the lower end of the injector as a "cup" [15].

\section{Design calculation of the proposed pile basic parameters.}

\subsection{Calculation parameters in controlled broadening development.}

Evaluated is the radial movement of the membrane cup wall $\mathrm{u} 1$ under injection pressure depending on the required depth of the broadening in the soil massif (pile length), injection pressure and the volume of solution, as well as the stress-strain state of soil under the foundation based on the analytical solutions after O. Hoffman, et al. [16-17]:

$$
V=\frac{4}{3} \cdot \pi \cdot\left(r_{b}+u_{1}\right)^{3} \Rightarrow u_{1}=\left(\frac{3 \cdot V}{4 \cdot \pi}\right)^{\frac{1}{3}}-r_{b}
$$

in elastic stage with $p_{\text {in } 1} \leq p_{c r 1}$ :

$$
u_{1}=\left(p_{\text {in } 1}-\sigma_{01}\right) \cdot\left(A_{21}+A_{22} \cdot\left(\frac{1+w}{2}\right)\right) \cdot \frac{1}{E}
$$

in elastic-plastic stage with $p_{i n 1}>p_{\text {cr } 1 \text { : }}$

$$
u_{1}=\frac{1}{E} \cdot A \cdot p_{c r} \cdot k_{r}{ }^{\beta}+\frac{1}{E} \cdot M \cdot \frac{2 \cdot\left(1-k_{r}{ }^{1-\alpha+\beta}\right)}{1+\beta-\alpha}-\frac{1}{E} \cdot N \cdot \frac{1-k_{r}{ }^{1+\beta}}{1+\beta}
$$




\section{TPACEE-2016}

where $r_{b}$ - initial radius (depends on the screw diameter), $r_{c}=0.04 \mathrm{~m}$;

$E$ - deformation modulus in the broadening zone, $\mathrm{kPa}$;

$p_{\text {in } 1}$ - solution injection pressure on the membrane cup walls, $\mathrm{kPa}$;

$\alpha=\frac{12 \cdot \sin \varphi_{0}}{3+3 \cdot \cos \varphi_{0}}, s=1 ; \beta=\frac{2 \cdot\left(1-\sin \varphi_{0}\right)}{1+\sin \varphi_{0}} ;$

$\beta_{1}=A_{11}+\beta \cdot A_{21}, \beta_{2}=A_{12}+\beta \cdot A_{22} ; A=\left(A_{21}+A_{22} \cdot\left(\frac{1+w}{2}\right)\right.$

$M=\left(\beta_{1}+\beta_{2} \cdot(1-\alpha)\right) \cdot\left(p_{c r}+s\right) ; N=\left(\beta_{1}+\beta_{2}\right) \cdot s ;$

$\sigma_{01}-$ horizontal side deadweight contact soil pressure, $\mathrm{kPa}$;

$\sigma_{01}=\frac{\left(2 \cdot \sigma_{h}+\sigma_{z}\right)}{3}=\frac{2 \cdot\left(\gamma_{g r} \cdot z \cdot \frac{v}{1-v}\right)+\gamma_{g r} \cdot z}{3}$

$\gamma_{g r}$ - gravity weight of the soil massif, $\mathrm{kN} / \mathrm{m}^{2} ; \mathrm{z}$-depth, m;

$v$ - Poisson ratio; $\varphi_{0}$ - angle of internal friction;

$p_{c r 1}$ - critical pressure $\mathrm{kPa}$ of the membrane on the soil massif during solution injection when its elastic strains become plastic ones:

$$
\begin{aligned}
& p_{c r 1}=\frac{4 \cdot\left(\sigma_{0} \cdot \sin \varphi_{0}+c \cdot \cos \varphi_{0}\right)}{\left(1-w-\sin \varphi_{0}(3+w)\right)} \\
& w=\frac{A_{12}-2 \cdot A_{21}-2 \cdot A_{22}}{2 \cdot A_{22}}-\frac{\sqrt{4 \cdot A_{21}^{2}-4 \cdot A_{21} \cdot A_{12}+A_{12}^{2}+8 \cdot A_{22} \cdot A_{11}+A_{22}^{2}+2 \cdot A_{22} \cdot A_{12}+20 \cdot A_{22} \cdot A_{21}}}{2 \cdot A_{22}} \\
& A_{11}=1, A_{12}=-2 \cdot \lambda \cdot v, A_{21}=-v, A_{22}=\lambda \cdot(1-v)
\end{aligned}
$$

$\lambda$ - multimodulus factor (ratio of compressive deformation modulus $E$ to tensile deformation modulus $E_{t}$ ) allows the elastic-plastic characteristics of silty-clayed soil to be considered; it ranges from 1.0 to 5.0 depending on the type of clay and soil moisture. Fig. 2

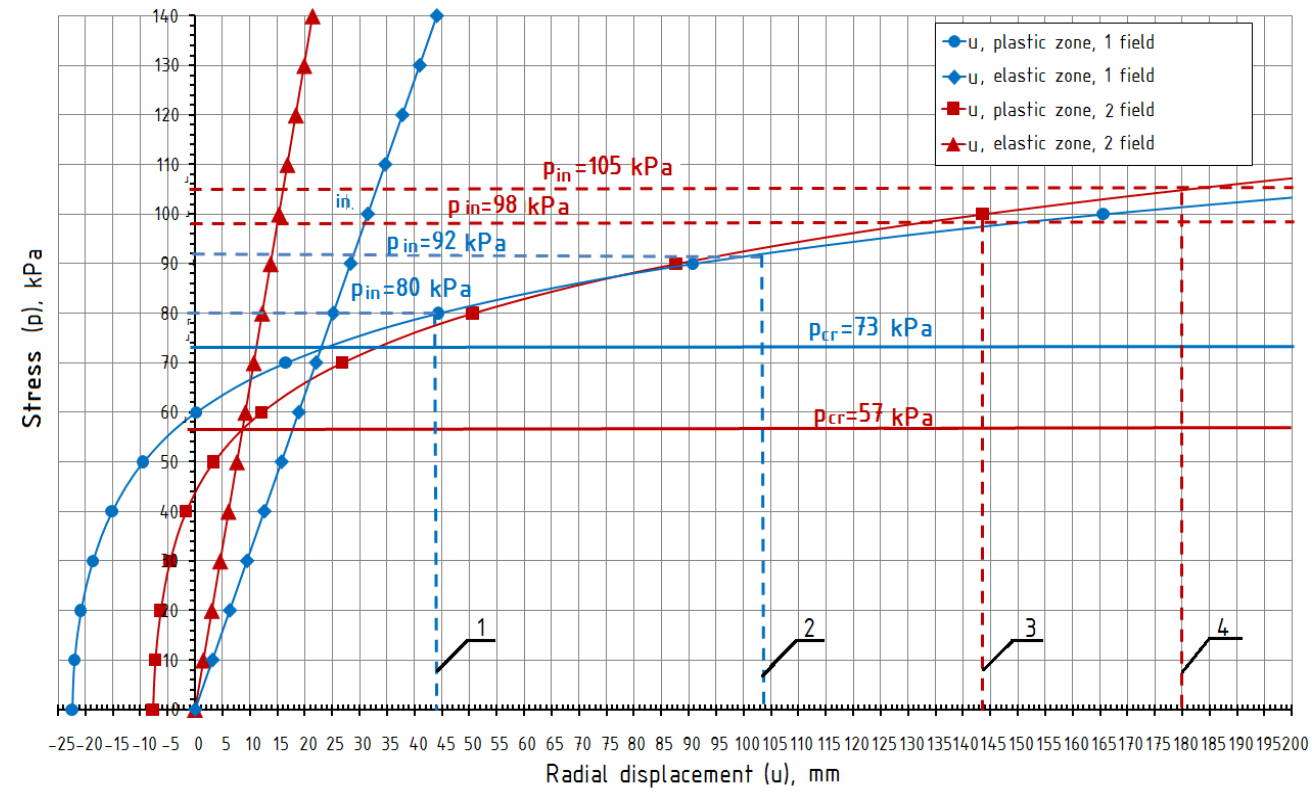

Fig.2. Dependency diagram $u_{1}$ from acting solution injection pressure in elastic and plastic zones of the soil massif: 1,2 - on the 1 st site $\mathrm{V}=10$ and 201 correspondingly; 3,4 - on the $2 \mathrm{~d}$ site $\mathrm{V}=30$ and 401 correspondingly. 


\section{TPACEE-2016}

Evaluated is the radius of the compacted zone depending on $u_{1}$ :

$$
R_{\text {com } 1}=\left(r_{c}+u_{1}\right) \cdot k_{r 1}, k_{r}=\left(\frac{p_{i n}^{1}+s}{p_{c r}^{1}+s}\right)^{\frac{1}{\alpha}}
$$

Evaluated are the residual stresses $\sigma_{r}^{r e s}$ depending on $u_{1}$ and $R_{\text {com } 1}$ :

$$
\begin{gathered}
\sigma_{r}^{r e s}=\sigma_{r}-\sigma_{r}^{*} \\
\sigma_{r}=-\frac{p_{i n} \cdot\left(r_{c}+u_{1}\right)^{n}}{R_{c o m 1}^{n}-\left(r_{c}+u_{1}\right)^{n}} \cdot\left(\frac{R_{c o m 1}^{n}}{r^{n}}+1\right), \sigma_{r}^{*}=-\frac{p_{i n} \cdot\left(r_{c}+u_{1}\right)^{2}}{R_{c o m 1}^{2}-\left(r_{c}+u_{1}\right)^{2}} \cdot\left(\frac{R_{c o m 1}^{2}}{r^{n}}+1\right)
\end{gathered}
$$

where $n$ - factor to be determined from the power law of deformation under shear, $\tau=\tau_{0} \cdot \gamma^{\frac{n}{2}}, n$-varies in the range of $0<n<2$ depending on the type of soil and its water saturation; in calculations it is determined on the basis of experimental data -parameters of soil pressure cells when broadening, $n=1.55$.

\subsection{Calculation Parameters in pile shaft development.}

The radial movement of the borehole wall $u_{2}$ under the action of injection pressure $p_{\text {in } 2}$, depending on the pile length of solution injection pressure under the condition $p_{\text {req }}>p_{\text {in } 2}>p_{\text {cr } 2}$, based on the analytical solutions after Z.G. Ter-Martirosyan, V.G. Fedorovsky, A.I. Polishchuk [18-19] et al. is evaluated by the formulas.:

in elastic stage of broadening with $p_{i n 2} \leq p_{c r}$

$$
u_{2}=\left(p_{\text {in } 2}-\sigma_{02}\right) \cdot\left(A_{21}+\cdot A_{22} \cdot(1+w)\right) \cdot \frac{1}{E}
$$

in elastic-plastic stage of broadening with $p_{\text {req }}>p_{\text {in2 }}>p_{c r}$

$$
u_{2}=\frac{1}{E} \cdot A \cdot p_{c r 2} \cdot k_{r 2}{ }^{\beta}+\frac{1}{E} \cdot M \cdot \frac{1-k_{r 2}{ }^{1-\alpha+\beta}}{1+\beta-\alpha}-\frac{1}{E} \cdot N \cdot \frac{1-k_{r 2}{ }^{1+\beta}}{1+\beta}
$$

where $p_{i n 2}$-solution injection pressure acting on the borehole walls, $\mathrm{kPa}$;

$\sigma_{02}$-side contact soil pressure, $\mathrm{kPa}$ :

$$
\begin{aligned}
& \sigma_{02}=\gamma_{g r} \cdot z \cdot v /(1-v) \\
& \alpha=\frac{2 \cdot \sin \varphi_{0}}{1+\sin \varphi_{0}}, s=\frac{c \cdot \cos \varphi_{0}}{\sin \varphi_{0}}, A=A_{21}+(1+w) \cdot A_{22}, \\
& \beta=\frac{1-\sin \varphi_{0}}{1+\sin \varphi_{0}}, \beta_{1}=A_{11}+\beta \cdot A_{21}, \beta_{2}=A_{12}+\beta \cdot A_{22} \\
& M=\left(\beta_{1}+\beta_{2} \cdot(1-\alpha)\right) \cdot\left(p_{c r 2}+s\right), N=\left(\beta_{1}+\beta_{2}\right) \cdot s
\end{aligned}
$$

$p_{c r 2}-$ critical pressure, $\mathrm{kPa}$, corresponding to the initial plastic strains is evaluated by the formula:

$$
\begin{aligned}
& p_{c r}=\frac{-2\left(\sigma_{0} \cdot \sin \varphi_{0}+c \cdot \cos \varphi_{0}\right)}{(w+2) \sin \varphi+w} \\
& w=\frac{-A_{21}+A_{12}-2 \cdot A_{22}-\sqrt{A_{21}^{2}-2 \cdot A_{21} \cdot A_{12}+A_{12}^{2}+4 \cdot A_{22} \cdot A_{11}}}{2 \cdot A_{22}} \\
& A_{11}=1-v^{2}, A_{12}=-\lambda \cdot v \cdot(1+v), A_{21}=-v \cdot(1+v), A_{22}=\lambda \cdot\left(1-v^{2}\right) \\
& p_{r e q}-\text { hydraulic fracture pressure, } \mathrm{kPa}, \text { is evaluated by the formula (24); }
\end{aligned}
$$


Evaluated is the radius of the neighboring compacted soil massif zone due to the pile shaft diameter increase under solution injection pressure $R_{\text {com } 2}$, depending on $u_{2}$ :

$$
R_{c o m 2}=\left(r_{b}+u_{2}\right) \cdot k_{r 2}, \quad k_{r 2}=\left(\frac{p_{i n 2}+s}{p_{c r 2}+s}\right)^{\frac{1}{\alpha}}
$$

\subsection{Calculation parameters in hydraulic fractures development}

Evaluated is $p_{\text {req }}$, depending on the depth of the injection horizon $z$, gravity weight of the soil massif and its mechanical strength characteristics $-C$ и $\varphi$, as well as the strength of soil-concrete in compression (tension) $\sigma_{c}, \sigma_{t}$, - necessary to be taken into account in repeated solution injection in the "fracturing" mode $[10,12]$ :

$$
\begin{aligned}
& p_{\text {req }}=\gamma \cdot z \cdot(1+\sqrt{3} \cdot \operatorname{tg} \varphi)+\frac{2}{\sqrt{3}} \cdot C, \\
& \text { где } \mathrm{C}=\frac{\frac{2}{\sqrt{3}} \cdot \sigma_{c} \cdot \sigma_{t}}{\sigma_{c}+\sigma_{t}}, f=\frac{\sqrt{3} \cdot\left(\sigma_{c}-\sigma_{t}\right)}{\left(\sigma_{c}+\sigma_{t}\right)}
\end{aligned}
$$

Evaluated is the radius of hydraulic fracture expansion $R_{\text {fractur }}$ depending on the interval of perforations and their quantity in the injector tube section, as well as the type of injection (single or repeated); due to their random development and uncontrolled expansion, $R_{\text {fractur }}$ is taken after the in-situ tests minus $R_{\text {com } 2}$;

The radius of the neighboring compacted soil massif zone is evaluated with regard to:

hydraulic fractures: $R_{\text {com } 3}=R_{\text {ycom } 2}+R_{\text {fractur }}$

change of mechanical characteristics $E_{c o m 2}, e_{c o m 2}, \mathrm{C}_{c o m 3}$, proceeding from the radius of their expansion and the solution volume $V_{s}$, subjected to injection upon $1 \mathrm{rm}$ of the pile length [20-21]:

$$
E_{\text {com } 2}=\frac{E_{\mathrm{c}}+E_{\mathrm{a}}}{2}
$$

where $e_{a}, E_{a}-$ air void ratio and modulus of deformation of soil massif reinforced by hydraulic fractures, MPa. It is evaluated by the formula (28);

$e_{\mathrm{c}}, E_{\mathrm{c}}-$ air void ratio and modulus of deformation of soil massif compacted between fractures, MPa.;

$e_{d}, E_{d}-$ initial modulus of deformation and air void ratio of soil;

$E_{s}-$ modulus of deformation of solution injected into soil massif is taken equal to $E_{s}=8000 \mathrm{MPa}$;

$k_{a}$ - factor reflecting the proportion of hardened solution in the cracks of hydraulic fracture (minus air void filling) in a given volume of soil massif;

$V_{\mathrm{p}}-$ air void volume in the soil massif under study $V_{d}, \mathrm{~m}^{3}$;

The coefficient of compaction $C_{c o m}$. is determined by SP 50-101-2004 with substitution of value $e_{\text {com }}$.

\subsection{Evaluated is the regularity of settlement development in static loading}

The settlement-load comparative diagrams (Fig.3) were plotted on the basis of the elasticplastic model after S.P. Timoshenko and the analytical solutions after Z.G. Ter-Martirosyan [17-18] taking into account the changes in the mechanical properties of the neighboring compacted soil massif zone and preservation of the residual stresses up to the load the pressure of which does not exceed the value $\sigma_{r}^{r e s}$ in the formulas $(12,27)$. 
a)

$0 \quad 102030 \quad 40506070 \quad 8090100110120130140150160170$

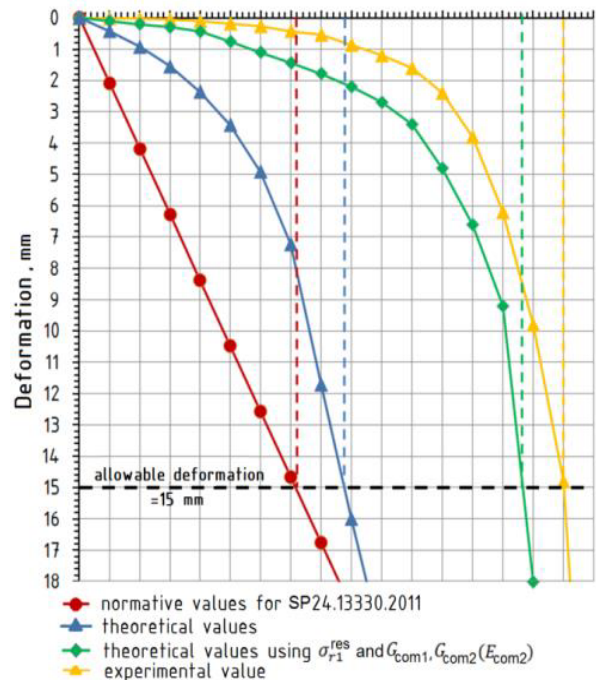

c)

Loading, $\mathrm{kN}$

$\begin{array}{lllllllllllll}0 & 5 & 10 & 15 & 20 & 25 & 30 & 35 & 40 & 45 & 50 & 55 & 60\end{array}$

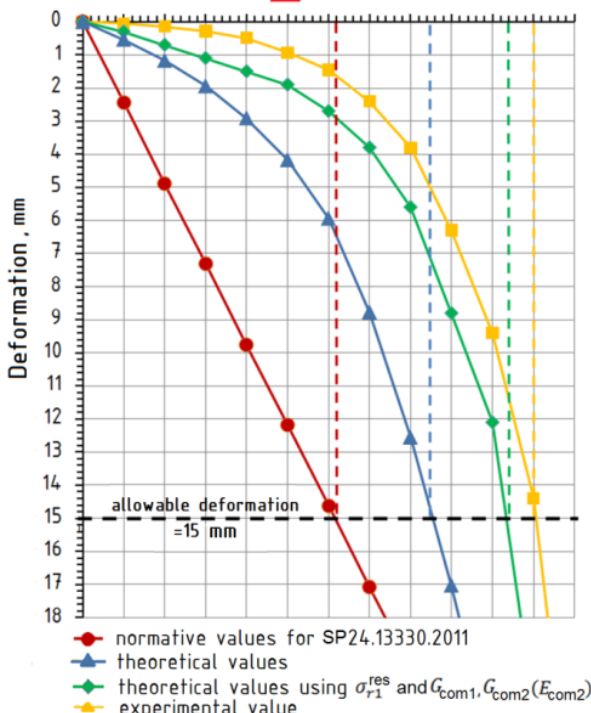

L) Loding, kN
$0102030 \quad 405060 \quad 70 \quad 8090100110120130140150160170180190200$

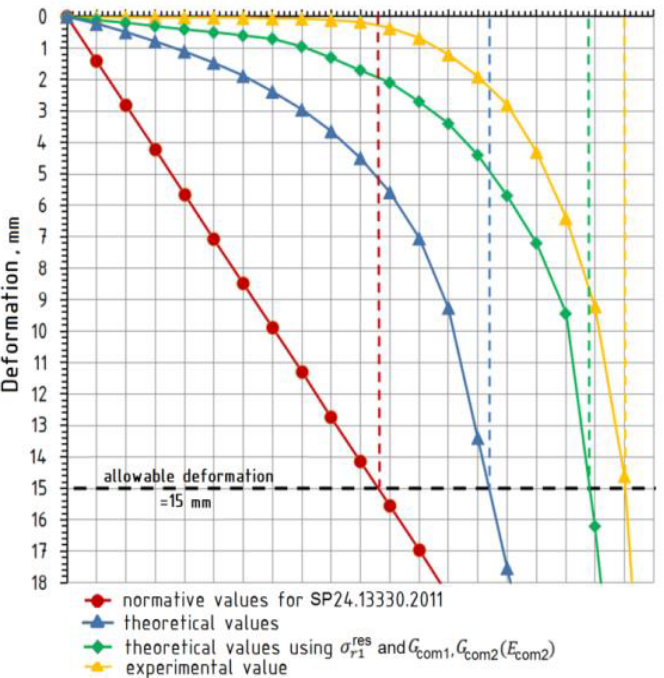

d) Loading, $\mathrm{kN}$

d) $\begin{array}{llllllllllllllll}0 & 5 & 10 & 15 & 20 & 25 & 30 & 35 & 40 & 45 & 50 & 55 & 60 & 65 & 70 & 75\end{array}$

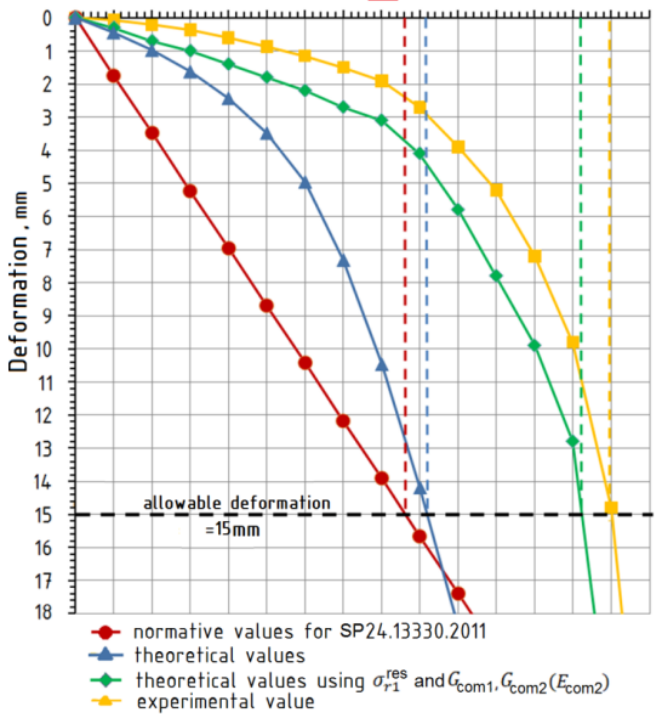

Fig.3. Settlement-load comparative diagrams $s=f(p)$ for drill-injection piles with the controlled broadening and the repeated solution injection in the "fracturing" mode: a), b) on the 1st site V=10$20 \mathrm{l}$; c), d) on the $2 \mathrm{~d}$ site $\mathrm{V}=30-40 \mathrm{l}$.

$$
\begin{aligned}
& E_{c o m 1}=\frac{(1+v) \cdot\left(1-\frac{v}{(1-v)}\right)}{\left(\frac{e_{c o m} \cdot\left(1+e_{0}\right)}{p_{\text {in }}-\sigma_{0}}\right)} \cdot \frac{\sigma_{r}^{r e s} \cdot \operatorname{tg} \varphi}{\sigma_{r}^{r e s} \cdot \operatorname{tg} \varphi-\sigma_{0} \cdot \frac{\left(1-\frac{v}{(1-v)}\right)}{\sqrt{3}}} \\
& S=\frac{N}{\pi \cdot\left(r_{b}+u_{1}\right) \cdot G_{c o m}+2 \cdot \pi \cdot l \cdot G_{c o m} 2} \cdot \ln \frac{\left(\tau^{*} \cdot\left(\frac{R_{c o m 1} 1}{r_{b}+u_{1}}+\frac{R_{c o m}(3)}{r_{b}+u_{2}}\right)-\tau_{u}\right)}{\left(\tau^{*}-\tau_{u}\right)}
\end{aligned}
$$




\section{The results of in-situ tests}

To determine the geometric parameters of the proposed piles and the changes in physical and mechanical characteristics of the soil massif, excavation of piles was carried out layer by layer after in-situ tests and installation of piles. (Fig. 4)

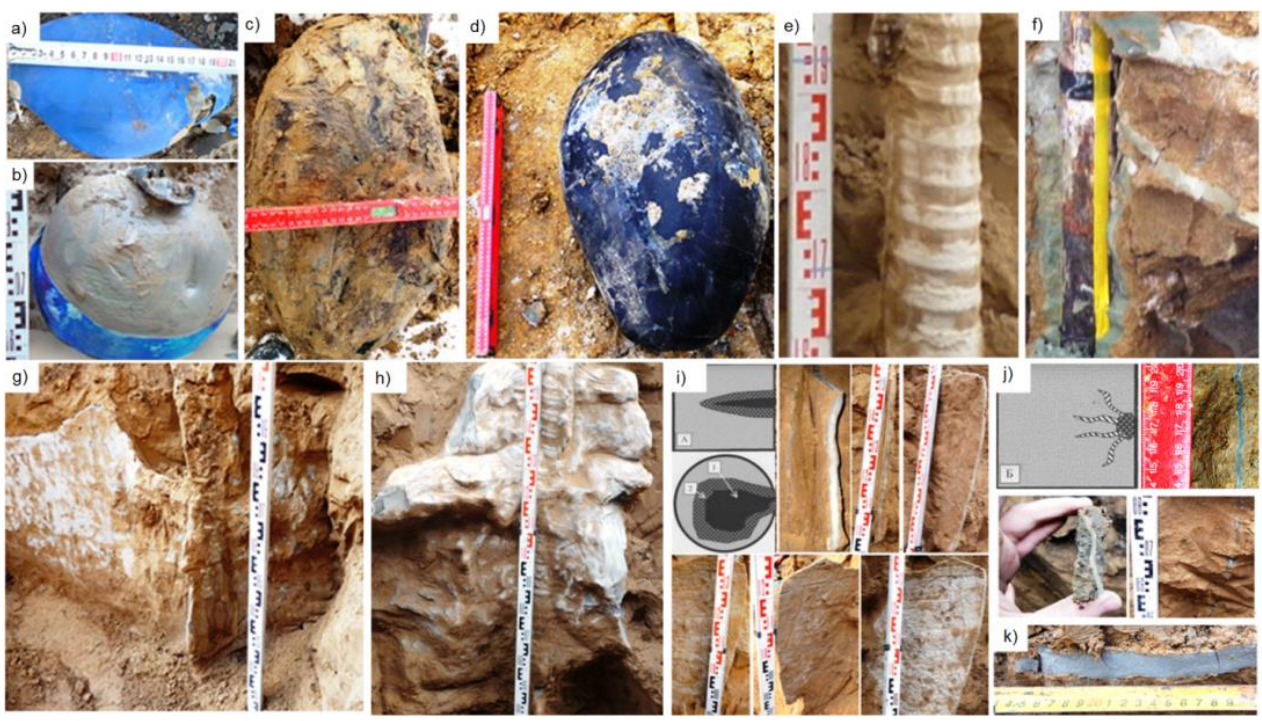

Fig. 4. Geometric parameters of the proposed piles: a, b - controlled broadenings V=10-20 1, c, d 30-40 1, e - pile shaft diameter increase, $\mathrm{f}$ - hydraulic fractures development, $\mathrm{g}, \mathrm{h}$ - expansion of hydraulic fractures in single and repeated solution injections, $i, j-$ texture of hydraulic fractures of «A» and «B» types, $\mathrm{k}$ - horizontal hydraulic fractures.

After the excavation it was found out that a horizontally elongated elliptical controlled broadening of 250-350 mm in diameter with the ratio of $\mathrm{d} / \mathrm{h}=1.3-1.4$ was formed at the pile end in the solution injection of $\mathrm{V}=10-201$ into the membrane cup. When the solution injection was $\mathrm{V}=30-40$ 1, the vertically elongated broadening of 360-390 $\mathrm{mm}$ in diameter with the ratio of $\mathrm{d} / \mathrm{h}=0.7-08$ was formed. The difference in values was due to the different pile lengths - 2 and $6 \mathrm{~m}$ correspondingly. The pile shaft diameter nearly doubled when the drill-injection pile shaft was formed by the sleeve technology with solution injection using the "fracturing" mode due to permanent pressure on the borehole walls with a mean value of $0.2 \mathrm{MPa}$. Hydraulic fractures up to $40 \mathrm{~mm}$ in thickness expanded to a considerable distance from the pile, up to $3 \mathrm{~m}$ in a single solution injection. Hydraulic fractures localized in the neighboring soil massif up to $130 \mathrm{~mm}$ in thickness at a distance of $0.5 \mathrm{~m}$ from the injector in repeated solution injection. In accordance with the classification of I.I. Sakharov two types of hydraulic fracture textures were found out: type "A" in the form of the greater crack growth with development of solid lens of 10-130 mm in thickness and type "B" - numerous thin cracks up to $5 \mathrm{~mm}$ in thickness, loosely filled with the solution [10].

Analysis of changes in the physical and mechanical characteristics of the neighboring soil massif showed that the greatest change occurred in the compacted soil massif zone in controlled broadening development: the density increased on the average by $25 \%$, the moisture content decreased on the average by $38 \%$, the modulus of deformation increased by $60 \%$; the density along the pile shaft increased on the average up to $17 \%$, the moisture content decreased up to $28 \%$, the modulus of deformation increased up to $35 \%$. - these must be considered in future in design calculation of the basic parameters of the drillinjection pile and forecast its interaction with soil foundation [19-23]. 


\section{Conclusions}

1. Developed is a new method for strip foundation strengthening in buildings and structures erected on silty-clayed soils; it makes it possible to combine drill-injection pile installation with the controlled broadening, sleeve technology with solution injection using the "fracturing" mode (including repeated injections) along any layer of the soil massif and to restore foundation members as an integrated technological unit, thus greatly improving its effectiveness.

2. It was established that in controlled broadening development of 10-40 1 in volume, minimum diameter of the broadening was from 250 to $390 \mathrm{~mm}$, the compacted soil massif zone developed with an average radius of expansion of 0.15-0.6 $\mathrm{m}$ from the injector tube and a significant change in physical and mechanical properties: the density increased on the average by $25 \%$, the moisture content decreased up to $37 \%$, the modulus of deformation increased by $64 \%$, - these must be considered in future in design calculation of the basic parameters of the controlled broadening.

3. It was established that in drill injection pile shaft development one should do only the repeated solution injection using the "fracturing" mode when the number of hydraulic fractures and their localization increased in the neighboring soil massif at a distance of 0.5 $\mathrm{m}$ from the injector tube (at a maximum crack growth up to130 $\mathrm{mm}$ ) resulting in the pile bearing capacity increase on the average by $20 \%$. Also it was found out that due to the permanent pressure on the borehole wall with a mean value of $0.2 \mathrm{MPa}$, the diameter of the pile shaft nearly doubled and together with hydraulic fractures resulted in compacted zone development with the mean radius of $0.2-0.4 \mathrm{~m}$ from the injector tube and the changes in physical and mechanical properties within this zone: the density increased on the average by $17 \%$, the moisture content decreased up to $28 \%$, the modulus of deformation increased by $35 \%$, - these must be considered in future in design calculation of the pile shaft parameters.

4.The results obtained after the in-situ tests made it possible to develop the algorithm for design calculation of the basic parameters allowing the following accuracy: to evaluate the radius of the compacted zone in the controlled broadening and the neighboring soil massif - up to $7 \%$; to evaluate radial movements of the membrane cup walls and borehole up to 10 and $14 \%$ correspondingly; to forecast settlement-load dependency in the proposed piles in silty-clayed soil loaded statically - up to $25 \%$.

\section{References}

1. V.F. Baj, T.V. Mal'ceva, A.N. Kraev, Nauchno-tekhnicheskij vestnik Povolzh'ya, 5, 108-111 (2014)

2. M.N Ibragimov, V.V. Semkin, Zakreplenie gruntov in"ekciej cementnyh rastvorov. Monografiya (ASV, Moscow, 2012)

3. V.V, Semkin, M.N. Ibragimov, Ya.Ya. Motuzov, Sbornik nauchnyh trudov NIIOSP, (2006)

4. V.A. Il'ichev, P.A. Konovalov, N.S. Nikiforova, Osnovaniya, fundamenty i mekhanika gruntov, 4, 19-24 (2001)

5. R.A. Mangushev, A.I. Osokin, Sovremennye svajnye tekhnologii (ASV, Moskva, 2007)

6. V.P. Petruhin, O.A. Shulyat'ev, O.A. Mozgacheva, Novye sposoby geotekhnicheskogo stroitel'stva (ASV, Moscow, 2015)

7. H. Brandl, Proceedings of the Twelfth International Conference on Soil Mechanics and Foundation Engineering, Rotterdam, (1992)

8. H.G. Poulos, E.N. Devis, Pile foundation analysis and design (Wiley, 2000)

9. Ya.A. Pronozin, Yu.V. Zazulya, R.V. Mel'nikov, M.A. Stepanov, Sovremennye problemy nauki i obrazovaniya, $\mathbf{3},(2013)$ 
10. I.I. Saharov, M.A, Abbud, Geotekhnika. Nauka i praktika: sb. nauch. tr., 72-76 (2000)

11. Z.G. Ter-Martirosyan, Ya.A. Pronozin, M.A. Stepanov, Soil Mechanics and Foundation Engineering, 1-5 (2012)

12. E.S. Voznesenskaya, V.A. Ermolaev, A.I. Osokin, S.V. Tatarinov, OFMG, 4, 19-23. (2014)

13. L. Gabrielaitis, V. Papinigis, G. Zarzojus, Procedia Engineering, 57, 287-293 (2013)

14. Ya.A. Pronozin, M.A. Samohvalov, D.V. Rachkov, Promyshlennoe i grazhdanskoe stroitel'stvo, 3, 56-60 (2014)

15. Ya.A. Pronozin, Yu.V. Zazulya, M.A. Samohvalov, Sposob izgotovleniya buroin"ekcionnoj svai s kontroliruemym ushireniem, Patent 2522358 Rossijskaya Federaciya, MPK-2014.07 E 02 D 5/46. (2014)

16. O Hoffman, G. Sachs, Introduction to the theory of plasticity for engineers (McGRAW-HILL BOOK COMPANY, New York, 1953)

17. Z.G. Ter-Martirosyan, A.S.M. Abdul Malek, OFMG, 6, 8-11 (2007)

18. Z.G. Ter-Martirosyan, V.S. Avanesov, Vestnik MGSU, 47-54 (2015)

19. A.I. Polishchuk, Osnovy proektirovaniya $i$ ustrojstva fundamentov rekonstruiruemyh zdanij (STT, Moscow, 2004)

20. R.H. Karol, Chemical grouting and soil stabilization, Basel (Marcel Dekker, Inc., New York, 2003)

21. L. Gabrielaitis, V. Papinigis, J. Sirvydaite, Engineering Structures and Technologies, 4(1), 7-15 (2012)

22. L. Epifantceva, O. Poroshin, Y. Pronozin, 10th International Conference on Geosynthetics, ICG (2014)

23. Z.G. Ter-Martirosyan, Y.A. Pronozin, N.Y. Kiselev, Soil Mechanics and Foundation Engineering (2014) 